\title{
Causal Effect of Parents' Play Participation Level and Play Participation Attitude on Preschooler's Executive Function
}

\author{
Sun Jung Baik ${ }^{1}$, Hee Hwa Kim ${ }^{2}$ \\ M. A., Department of Child Development and Family Studies, Pusan National University, Busan, Korea ${ }^{1}$ \\ Professor, Department of Child Development and Family Studies, Pusan National University, Busan, Korea ${ }^{2}$

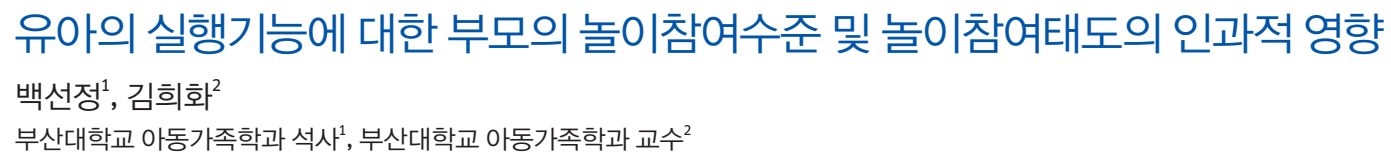

Objectives: Current study aims to examine the relationship between parents' play participation level, play participation attitude, and preschooler's executive function. Also, it aims to evaluate whether parents' play participation attitude mediates the relationship between parents' play participation level and preschooler's executive function.

Methods: A total of 193 mothers and fathers of preschoolers aged 3,4 and 5 years participated in the mother-father dyads. Data were collected using questionnaires and were analyzed using SPSS 25.0 and Amos 25.0 programs.

Results: While parents' play participation level did not have a direct effect on the preschooler's executive function, the parents' responsively and delightfully play mediated the association between parents' play participation level and preschooler's executive function. Further, parents' sensitively play, responsively and delightfully play had dual mediation effect between parents' play participation level and preschooler's executive function.

Conclusion: These results identify that preschooler's executive function can be developed by parents' play attitude when parents' play participation level is high. In addition, results suggest that both parents' play variables play important roles on preschoolers' executive function development. The results can be used for the development of parent education program or consultant program.

Keywords: parents' play participation level, parents' play participation attitude, preschooler's executive function

\section{Introduction}

실행기능이란 문제를 해결하기 위해 필요한 고차원적 인지 능력 중 하나로, 문제해결전략을 계획하고 기억하며 유연하 게 사고하는 능력을 뜻한다. 실행기능은 만 3 세에서 5세 사이 에 관련 기술들이 협응하여 사용되기 시작하면서 중요한 발

Corresponding Author: Hee Hwa Kim, Professor, Department of Child Development and Family Studies, Pusan National University, 2, Busandaehakro 63beon-gil, Geumjeong-gu, Busan, Korea

E-mail: hwakim@pusan.ac.kr
달적 변화를 보이기 때문에(Cha, 2018) 학자들은 이 시기의 실 행기능에 주목하고 있다. 특히 유아기의 실행기능은 언어 능 력(Blair \& Razza, 2007; Y.-M. Kim, 2018), 수학적 능력(Blair \& Razza, 2007)과 같은 인지발달 및 친사회적 행동(Kong, 2012; Moore, Barresi, \& Thompson, 1998), 또래유능성(B. Y. Kim. 2016), 정서조절(R. H. Yoo \& Kim, 2017)과 같은 사회·정서적

(C)The Korean Association of Child Studies

This is an Open Access article distributed under the terms of the Creative Commons Attribution Non-Commercial License (http:// creativecommons.org/licenses/by-nc/4.0) which permits unrestricted noncommercial use, distribution, and reproduction in any medium, provided the original work is properly cited. 
발달에 영향력 있는 기제로 밝혀지고 있어 중요성이 더욱 부 각되고 있다.

유아의 실행기능 발달은 주로 유아보다 인지적 수준이 높 은 성인과의 상호작용을 통해 일어나기 때문에(Sokol, Muller, Carpendale, Young, \& Iarocci, 2010) 실행기능 발달에 있어 유아와 오랜 시간 함께 보내는 성인인 부모의 양육적 역할 이 강조되어왔다(Distefano, Galinsky, McClelland, Zelazo, \& Carlson, 2018; Kwon, 2019; Y.-J. Lee, Kong, \& Lim, 2014; Meuwissen \& Carlson, 2015). 특히 유아는 놀이 과정에서 자 신의 정서와 욕구를 조절하는 방식을 습득하고 창의적으로 사고하는 기회를 갖게 됨으로써 실행기능을 발달시킬 수 있 기 때문에(Cemore \& Herwig, 2005; Kelly, Dissanayake, Ihsen, \& Hammond, 2011; E.-J. Park, 2017) 부모-유아 상호작용으 로 놀이상황에서의 부모참여에 주목해볼 필요가 있다. 부모 의 놀이참여변인에 대해 살펴본 기존 연구에서는 양적 변인 과 질적 변인을 구분하지 않고 하나의 변인으로 살펴보고 있 으나(H. M. Hong, 2018; Shin, 2019) 놀이에 얼마나 자주 참여 하는지를 살펴보는 양적 놀이참여변인과 놀이상황에서의 부 모의 민감성, 반응성, 즐거움 등을 살펴보는 질적 놀이참여변 인은 의미가 서로 구분되며, 유아의 발달에 미치는 역할에 차 이가 있음을 고려할 때(H.-S. Choi \& Kim, 2011; Y. Yoo, 2019) 이는 구분될 필요가 있다. 따라서 본 연구에서는 놀이참여의 양적 변인인 부모의 놀이참여수준과 질적 변인인 부모의 놀 이참여태도로 구분하고, 유아의 실행기능에 어떠한 영향을 미치는지 살펴보고자 한다.

놀이참여수준이란 부모가 놀이에 얼마나 자주 참여하는지 에 대한 수준을 의미한다. 유아는 부모와의 놀이경험을 통해 인지적 자극을 받거나 문제해결능력을 습득함으로써(TamisLeMonda, Shannon, Cabrera, \& Lamb, 2004) 실행기능을 발달 시킬 수 있다. 따라서 부모와의 놀이경험이 많은 유아일수록 실행기능 발달이 촉진될 것이라 추론된다. 부모의 반응적 양 육행동이 여아의 실행기능에 미치는 영향에 대해 밝힌 연구 (Cha \& Kim, 2018)에서 반응적 양육행동의 일부분으로 부모 의 놀이참여 정도를 살펴보고 있으나, 놀이 활동에 대한 정보 가 제한적이기 때문에 부모의 놀이참여수준과 유아의 실행기 능 간의 관계에 대해 구체적으로 알기 어렵다. 또한 아버지가 놀이에 자주 참여할수록 마음이론, 학습관련 기술 등과 같은 유아의 인지능력이 향상되었다는 연구(S. Y. Choi, 2017; Noh, 2006)를 통해 부모의 놀이참여수준과 관련 인지변인인 실행 기능과의 관련성을 유추해볼 수 있으나 두 변인 간의 직접적 인 관계에 대해 밝힌 연구는 찾아보기 힘들다. 따라서 본 연구
에서는 부모의 놀이참여수준과 유아의 실행기능 간에는 어떠 한 관련성이 있는지 밝히고자 한다.

놀이참여태도란 자녀와의 놀이에서 자녀에 대해 얼마나 민 감하게 인지하며 얼마나 적절한 반응을 보이는지에 관한 태도 로 정의된다(L. Kim \& Lee, 2018). 부모의 놀이참여태도와 유 아의 실행기능 간의 관계에 대해서 살펴본 연구는 없으나 유 아의 실행기능 발달에 도움이 되는 부모의 놀이참여태도에 대한 정보를 제시해주는 국외연구는 다수 이루어지고 있다. Tamis-LeMonda 등(2004)의 연구에서 부모가 놀이상황에서 유 아의 관점을 취하고 유아의 신호를 정확하게 인지하는 등 민 감하게 인지하는 반응을 보일수록 유아의 기억력이나 문제해 결력과 같은 인지능력이 발달하였다. 또한 몇몇의 연구에 따 르면 부모가 놀이상황에서 유아의 신호에 즉각적으로 반응하 거나, 유아의 속도에 맞추어 도움이 필요할 때 적절하게 반응 하고, 유아가 흥미를 보이는 것에 함께 참여하며, 칭찬 및 애 정을 표현할수록 유아의 실행기능(Distefano et al., 2018; Merz, Landry, Montroy, \& Williams, 2017; NICHD Early Child Care Research Network, 2005; Towe-Goodman et al., 2014)이 높았다. 놀이상황에서 부모의 이러한 태도는 유아로 하여금 놀이를 자 유롭게 선택하고 몰입하게 하는 등(L. Kim \& Lee, 2018) 놀이 의 질을 향상시켜 유아의 인지발달에 촉진적인 역할을 하기 때문이다(Ward, 1994). 이러한 결과에 의하면 유아의 실행기 능 발달에 도움이 될 수 있는 놀이참여태도는 놀이상황에서 부모가 유아에 대해 민감하게 인지하는 인지적 요소와 반응적 이고 즐겁게 노는 행동적 요소로 구분되어 이해될 필요가 있 음을 제시해 준다. 최근 국내에서는 부모의 이러한 놀이참여 특성이 반영된 놀이참여태도 척도가 개발된 바 있으며 본 연 구에서는 해당 척도를 인지적 요소인 민감하게 인지하기와 행 동적 요소인 반응적이고 즐겁게 놀기로 구분하여 유아의 실행 기능과 어떠한 관련이 있는지 살펴보고자 한다.

한편, 태도를 다루는 다수의 연구에서는 태도를 구성 하는 요인들 간의 인과관계에 대해서 관심을 보이고 있다 (Y. Hong, 2014; S.-J. Kim, Lee, \& Lee, 2002; K. Park \& Yoo, 2012). 본 연구에서도 부모의 놀이참여태도인 민감하게 인 지하기 및 반응적이고 즐겁게 놀기가 어떠한 과정을 통해 유 아의 실행기능에 영향을 주는지 명확히 이해하기 위해서 이 두 요인 간의 관계에 대해 주목하고자 한다. 태도에 대한 중 다차원 관점에서는 인지를 행동의 선행요인으로 설명하고 있다(Y. Hong, 2014). 이에 따르면 부모의 민감하게 인지하 기 놀이참여태도는 반응적이고 즐겁게 놀기 놀이참여태도 에 영향을 미침으로써 유아의 실행기능 발달에 도움을 줄 것 
으로 예측할 수 있다. 다시 말해, 부모가 유아에 대해 잘 알고 있을 때에는 유아가 필요한 도움이나 환경적인 자극을 즉각 적으로 제공해줄 수 있으며(Song, 2016) 상황에 맞게 공감이 나 격려를 보내거나 즐겁게 놀아줄 수 있기 때문에 유아의 실 행기능 발달 촉진에 도움이 될 것으로 생각된다. 선행연구에 서 유아의 비언어적인 행동을 잘 이해하고, 유아의 행동에 따 라 자녀의 상태를 잘 파악할 수 있는 등의 의사소통역량이 높 은 어머니일수록 자녀에게 반응적인 태도를 보이는 것으로 나 타났다(J.-E. Lee, 2013; J. Lim \& Kim, 2020). 또한 어머니가 유 아의 인지능력에 대해 정확히 인식할수록 유아의 능력에 따라 적절한 도움을 제공하는 행동을 더 많이 하는 것으로 보고되 었다(Cho \& Kim, 2005). 이러한 연구결과는 부모의 민감하게 인지하기 놀이참여태도가 유아의 실행기능에 영향을 미치는 데 있어 반응적이고 즐겁게 놀기 놀이참여태도가 매개할 것을 예측가능하게 해준다.

아울러 부모가 유아와 시간을 많이 보낼수록 인지적인 측 면에서 자녀에 대해 더 잘 알게 될 뿐만 아니라(Ishii-Kuntz, $1994)$ 행동적인 측면에서 긍정적인 상호작용을 주고받으면서 유아는 발달한다. 놀이와 관련하여서도 부모가 유아와의 놀이 에 자주 참여할수록 자녀의 놀이욕구나 놀이하면서 느끼는 감 정을 잘 이해하게 되며, 유아의 행동에 적절히 반응하고 상호 작용함으로써 유아의 실행기능 발달에 긍정적인 영향을 미칠 수 있다. 따라서 부모의 놀이참여수준이 높을수록 놀이참여태 도에 변화를 보임으로써 유아의 실행기능 발달에 긍정적인 영 향을 미칠 것으로 추정된다. 부모의 놀이참여수준과 놀이참여 태도의 직접적인 관계에 대해 살펴본 연구는 없으나, 아버지 의 양적 양육참여가 양육태도의 변화를 가져옴을 밝힌 선행 연구를 통해 두 변인 간의 관계에 대해 추정해볼 수 있다. H. J. $\operatorname{Kim}$ (1997)의 연구에 따르면 양육참여도가 높은 아버지일수 록 자녀에게 애정표현을 자주하며, 양육에 적극적으로 참여하 는 모습을 보이는 것으로 나타났다. G. Y. Kim과 Shin (2013)의 연구에서 주중의 놀이 활동 참여 빈도가 높을수록 아버지는 더욱 온정적이고 격려하는 양육행동을 보였으며, 비슷한 맥락 에서 J. H. Choi (2002)의 연구에서 아버지의 양육참여시간이 많을수록 자녀에게 더 반응적이며 친밀감을 많이 표현하였다. 이러한 선행연구들은 부모의 놀이참여수준과 놀이참여태도 간의 관련성에 대한 가능성을 보여준다. 종합해보면, 이러한 부모의 놀이참여수준과 놀이참여태도 간의 관계를 고려해볼 때 부모의 놀이참여수준과 놀이참여태도가 유아의 실행기능 에 각각 영향을 미칠 수도 있지만 부모의 놀이참여수준이 놀 이참여태도의 선행요인으로 작용하여 유아의 실행기능에 영
향을 미칠 것으로 예측된다.

한편, 유아의 실행기능과 관련된 선행연구에서는 어머니 변인 위주로 진행되어 왔다. 그러나 아버지 변인과 유아의 실 행기능을 살펴본 몇몇의 연구에서 아버지가 반응적 양육행동 을 보일수록 유아의 실행기능이 높았으며(Baek, 2019) 놀이상 황에서 아버지가 민감하고 지지적인 행동이 이후 유아의 실 행기능을 예측하였다는 결과(Towe-Goodman et al., 2014) 등이 보고되고 있다. 이는 실행기능 연구에서 아버지 역할 또한 비 중 있게 다루어져야 함을 시사한다. 특히, 어머니와는 달리 아 버지가 참여하는 양육 방식의 주된 특성은 놀이라는 점을 감 안하면(Bronstein \& Cowan, 1988), 놀이변인을 다루는 본 연구 에서는 아버지 놀이참여수준 및 놀이참여태도를 함께 다룸으 로써 의미 있는 정보를 제공할 수 있을 것으로 보인다.

본 연구의 목적은 다음과 같다. 먼저, 부모의 놀이참여수준 및 놀이참여태도와 유아의 실행기능 간의 관계에 대해 살펴보 고 다음으로, 부모의 놀이참여수준과 유아의 실행기능 간의 관계에서 부모의 민감하게 인지하기 및 반응적이고 즐겁게 놀 기 놀이참여태도는 매개적 역할을 하는지 살펴보고자 한다. 본 연구를 통해 유아의 실행기능 발달에 있어 부모와의 놀이 의 중요성을 강조하고, 부모교육 프로그램 및 부모상담에 도 움이 되는 기초자료를 제공하고자 한다.

\section{연구문제 1}

부모의 놀이참여수준 및 놀이참여태도와 유아의 실행기능 간 의 관계는 어떠한가?

\section{연구문제 2}

부모의 놀이참여태도는 부모의 놀이참여수준과 유아의 실행 기능 간의 관계를 매개하는가?

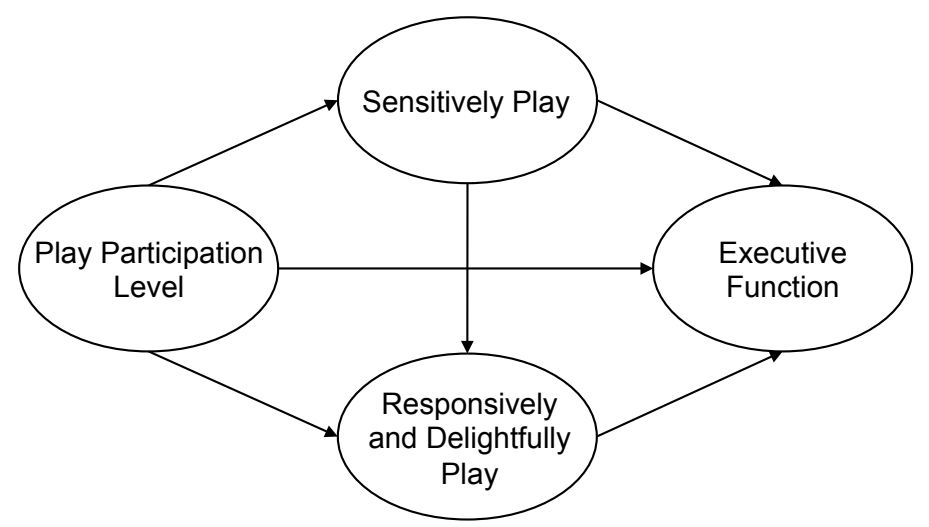

Figure 1. Theoretical model. 


\section{Methods}

\section{연구대상}

본 연구의 대상은 부산광역시 및 울산광역시에 소재한 유아 교육기관 9곳에 재원하고 있는 만 $3,4,5$ 세 유아의 어머니 및 아버지 193 쌍이다. 유아의 성별은 남아가 109 명 $(56.5 \%)$, 여아 가 84명(43.5\%)이었으며, 유아의 연령은 만 3세가 7명(3.6\%), 만4세가 45 명 $(23.3 \%)$, 만 5 세가 141 명(73.1\%)이었다. 어머니 의 연령은 30-39세가 124 명(64.2\%), 40-49세가 64명(33.2\%), 30 세 미만이 5명(2.6\%)순으로 많았으며, 아버지의 연령은 30-39세가 102명(52.8\%), 40-49세가 87명(45.1\%), 50세 이상 이 4 명 $(2.1 \%)$ 순으로 많았다. 어머니의 최종학력은 2,3 년제 전 문대학 졸업이 78명(40.4\%), 4년제 대학교 졸업 68명(35.2\%) 순으로 많았고, 아버지의 최종학력은 4년제 대학교 졸업 88명 (45.6\%), 2,3년제 전문대학 졸업 56명(29.0\%) 순으로 많았다. 어머니의 직업은 전업주부가 78 명 $(40.4 \%)$ 으로 가장 많았으 며 사무관리직이 34 명(19.6\%)로 뒤를 이었고, 아버지의 직업 은 전문기술직이 56명(29.0\%)으로 가장 많았으며 사무관리직 이 51명(26.4\%) 순으로 뒤를 이어 어머니와 다소 차이가 있었 다. 가계 월평균 수입은 600 만원 이상이 53 가구(27.5\%)로 가 장 많았으며 400-500만원 42가구(21.8\%), 300-400만원 34가 구(17.6\%) 등으로 나타났다.

\section{연구도구}

\section{유아의 실행기능}

유아의 실행기능을 측정하기 위해서 Isquith, Gioia와 Espy (2004)가 제작한 유아용 행동 평정 척도 Behavior Rating Inventory of Executive Function-Preschool version (BRIEF-P)를 Seo (2011)가 번안한 후 일부 문항을 명확하게 전달하기 위해 수정된 Baek (2019)의 척도를 사용하였다. 본 척도는 4점 리커 트 척도로 전혀 그렇지 않다(1점)에서 매우 그렇다(4점)로 측 정하며 모든 문항은 역채점되어 점수가 높을수록 실행기능이 높음을 의미한다. 하위요인은 억제, 전환, 작업기억, 계획조직 화, 감정조절로 구성되어 있으며 총 63 문항이다. 억제란 충동 적으로 행동하지 않고 자신의 행동을 조절할 수 있는 능력을, 전환은 문제에 유연하게 대처하고 전환할 수 있는 능력을, 작 업기억이란 문제를 해결하는데 필요한 정보를 기억할 수 있 는 능력을, 계획·조직화란 미래의 문제를 예측하며 목표를 설
정하고 전략을 세움으로써 조직화하는 능력을, 감정조절이 란 문제해결을 위해 자신의 정서를 조절할 수 있는 능력을 의 미한다. 본 변인은 객관성 확보를 위해 어머니와 아버지가 각 각 평정한 점수를 합산하여 사용하였다. Cronbach's $\alpha$ 값은 실 행기능 전체 Cronbach's $\alpha=.98$, 억제 Cronbach's $\alpha=.95$. 전환 Cronbach's $\alpha=.91$, 작업기억 Cronbach's $\alpha=.95$, 계획·조직화 Cronbach's $\alpha=.91$, 감정조절 Cronbach's $\alpha=.92$ 로 나타났다.

\section{어머니 및 아버지의 놀이참여수준}

어머니 및 아버지의 놀이참여수준을 측정하기 위해서 놀이참 여도를 측정하도록 고안된 Won (1998)의 척도를 본 연구에 맞 게 5점 리커트 척도로 수정하여 사용하였다. 어머니 및 아버 지의 놀이참여수준이란 어머니 및 아버지가 놀이에 얼마나 자 주 참여하는지에 대한 수준을 의미한다. 22 개 문항의 단일요 인으로 구성되어있으며, 전체 문항의 점수를 합산한 후 평균 을 산출하여 사용되었다. 자녀가 해당 놀이 자체를 하지 않을 경우를 감안하여 '자녀가 해당 놀이를 하지 않음' 항목을 추가 하였으며 이에 답한 문항은 총 합산 문항에서 제외한 후 평균 점수를 산출하였다. (참여를)전혀 하지 않는다(0점), (참여를) 아주 가끔 한다(1점), (참여를)종종 한다(2점), (참여를)자주 한 다(3점), (참여를)매우 자주 한다(4점)로, 평균점수가 높을수록 부모가 놀이에 많이 참여함을 의미한다. Cronbach's $\alpha$ 값은 어 머니의 놀이참여수준 Cronbach's $\alpha=.95$, 아버지의 놀이참여 수준 Cronbach's $\alpha=.97$ 로 나타났다.

\section{어머니 및 아버지의 놀이참여태도}

어머니 및 아버지의 놀이참여태도를 측정하기 위해서 L. Kim 과 Lee (2018)의 부모의 놀이참여태도 척도를 수정하여 사용 하였다. 본 척도에서는 놀이상황에서 부모가 유아의 언어적 및 비언어적 단서를 민감하게 인지하는가에 관한 인지적 태도 를 의미하는 '민감하게 인지하기'와 놀이상황에서 부모가 유 아에 대해 즉각적으로 반응하며 즐겁게 노는지에 관한 상호작 용 행동적 태도를 의미하는 '반응적이고 즐겁게 놀기'로 구분 하였으며, 18 번 문항과 19 번 문항은 의미상 행동적 태도와 거 리가 먼 것으로 판단되어 분석에서 제외시켰다. 본 척도는 5점 리커트 척도로 전혀 그렇지 않다(1점)에서 매우 그렇다(5점) 로 측정되며, 점수가 높을수록 해당 하위요인의 태도를 더 많 이 나타냄을 의미한다.

하위요인 별 Cronbach's $\alpha$ 값은 어머니의 민감하게 인지 
Table 1

Correlations Among Variables

\begin{tabular}{lcccc}
\hline \multicolumn{1}{c}{ Father's variables } & & & & \\
\multicolumn{1}{c}{ Mother's variables } & 1 & 2 & 3 & $.23^{* *}$ \\
\hline 1. Play participation level & - & $.58^{* *}$ & $.72^{* *}$ & $.19^{* *}$ \\
2. Sensitively play & $.45^{* *}$ & - & $.69^{* *}$ & $.31^{* *}$ \\
3. Responsively and delightfully play & $.64^{* *}$ & $.60^{* *}$ & - & - \\
4. Executive function & $.16^{*}$ & $.27^{* *}$ & $.35^{* *}$ & - \\
\hline
\end{tabular}

Note. $N=193$.

${ }^{*} p<.05 .{ }^{* *} p<.01$.

하기 Cronbach's $\alpha=.82$, 어머니의 반응적이고 즐겁게 놀기 Cronbach's $\alpha=.90$, 아버지의 민감하게 인지하기 Cronbach's $\alpha$ $=.83$, 아버지의 반응적이고 즐겁게 놀기 Cronbach's $\alpha=.93$ 으 로 나타났다.

\section{연구절차}

본 연구의 조사는 2020년 1 월 28일부터 2월 21일에 걸쳐 실시 되었다. 울산광역시 및 부산광역시에 소재하는 유아교육기관 을 임의로 선정하여 사전 연락을 통해 연구내용에 대해 설명 드린 후 직접 방문하여 설문지를 배부하였다. 해당 유아교육 기관으로부터 전달된 설문지는 연구에 관한 설명문과 함께 각 가정에 전달되었으며 어머니용 설문지는 어머니께서, 아버지 용 설문지는 아버지께서 각각 따로 응답하도록 하였다. 응답 완료된 설문지는 유아의 편으로 유아교육기관으로 다시 전달 되어 본 연구자가 해당 유아교육기관에 직접 방문하여 회수 하였다. 배부된 설문지 450 부 중 249부를 회수하였으며, 그 중 어머니 혹은 아버지 한 분만 응답하신 설문지 및 불성실한 설 문지는 제외한 후 총 193 부를 최종분석에 사용하였다.

\section{자료분석}

본 연구에서는 SPSS 25.0 프로그램(IBM Co., Armonk, NY)과 Amos 25.0 프로그램(IBM Co., Armonk, NY)을 사용하여 자료 를 분석하였다. 연구 대상자의 일반적 특성을 확인하기 위하여 빈도분석을 실시하였으며, 각 척도의 신뢰도 검증을 하기 위하 여 Cronbach's $\alpha$ 계수를 산출하고 기술통계를 실시하였다. 또 한 부모의 놀이참여수준, 부모의 놀이참여태도, 유아의 실행기 능 간의 관계를 알아보기 위하여 Pearson의 상관분석을 실시하 였다. 마지막으로, 부모의 놀이참여수준과 유아의 실행기능 간 의 관계에서 부모의 놀이참여태도의 매개효과를 알아보기 위 하여 구조방정식 분석을 통해 다중매개모델을 검증하고, 부트
스트래핑을 실시하여 간접효과의 유의성을 검증하였다.

\section{Results}

\section{측정변인들 간의 상관분석}

구조모형을 분석하기에 앞서 측정변인들 간의 상관관계를 알 아보기 위하여 Pearson의 상관관계 분석을 실시하였다. 그 결 과는 Table 1 과 같다. 유아의 실행기능은 어머니의 놀이참여수 준 $(r=.16, p<.05)$, 어머니의 민감하게 인지하기 놀이참여태 도 $(r=.27, p<.01)$, 어머니의 반응적이고 즐겁게 놀기 놀이참 여태도 $(r=.35, p<.01)$ 와 정적 상관이 나타났다. 또한 유아의 실행기능은 아버지의 놀이참여수준 $(r=.23, p<.01)$, 아버지의 민감하게 인지하기 놀이참여태도 $(r=.19, p<.01)$, 아버지의 반응적이고 즐겁게 놀기 놀이참여태도 $(r=.31, p<.01)$ 와 정적 상관이 나타났다.

\section{측정모형 분석}

본 연구의 측정변인들이 이론적 개념을 잘 반영하는지 검토 하기 위하여 확인적 요인분석을 실시하였다. 먼저 어머니 놀 이참여변인 측정모형의 적합도에서 카이제곱값은 83.76 , CMIN/DF는 2.04로 나타났으며, GFI는 .93, TLI는 .97, CFI는 .98, RMSEA는 0.7로 수용가능한 지수를 갖는 것으로 나타났 다. 이에 따른 요인부하량의 표준화된 계수는 Figure 2 와 같다. 모든 측정변인들은 .69 .96 사이의 값을 가지며, 모두 통계적 으로 유의한 것으로 나타났다 $(p<.001)$. 또한 잠재변인 간의 상관계수는 .33 .74 사이의 값을 가지는 것으로 나타났다. 따 라서 각 측정변인들은 수렴타당도 및 변별타당도를 만족시킴 을 알 수 있다.

다음으로 아버지 놀이참여변인의 측정모형의 적합도에서 


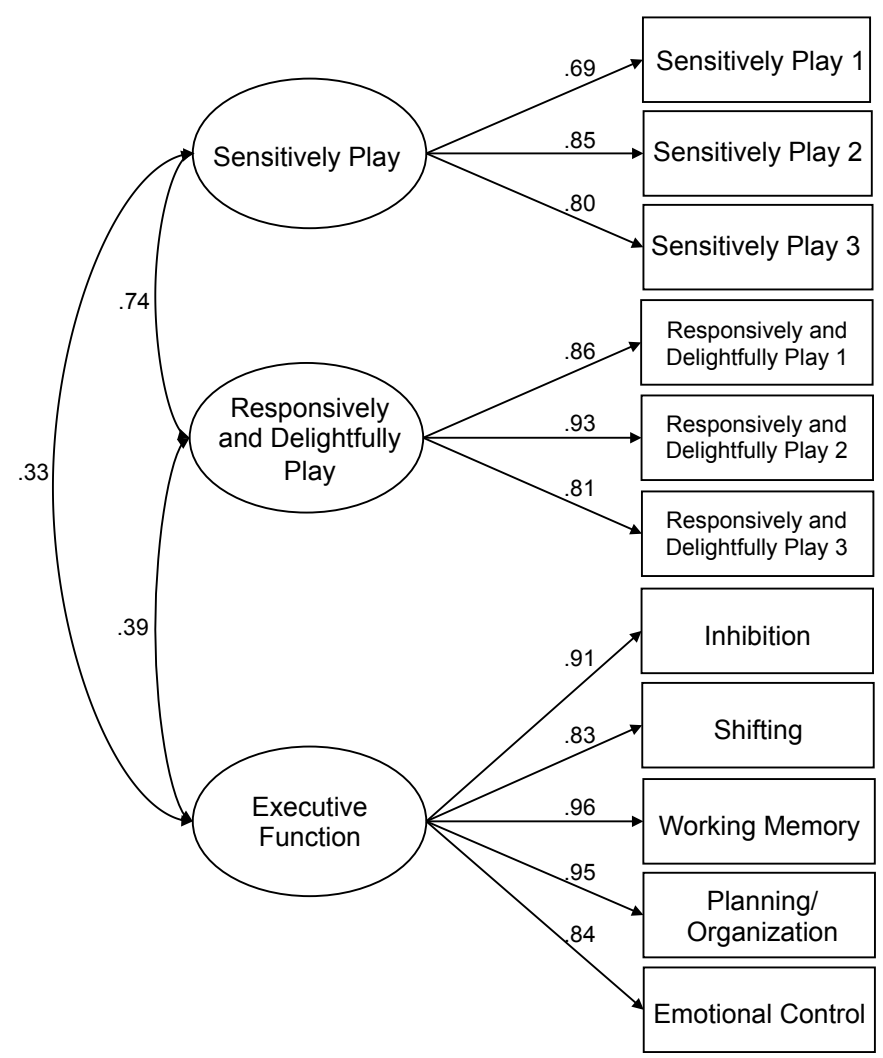

Figure 2. Confirmatory factor analysis of the measurement model of mother's variables.

카이제곱값은 90.91, CMIN/DF는 2.22로 나타났으며, GFI는 .92 , TLI는 $.97, \mathrm{CFI}$ 는 $.98, \mathrm{RMSEA}$ 는 0.8 로 수용가능한 지수를 갖는 것으로 나타났다. 이에 따른 요인부하량의 표준화된 계 수는 Figure 3과 같다. 모든 측정변인들은 .77 .96 사이의 값 을 가지며, 모두 통계적으로 의한 것으로 나타났다 $(p<.001)$. 또한 잠재변인 간의 상관계수는 .23 .78 사이의 값을 가지는 것으로 나타났다. 따라서 각 측정변인들은 수렴타당도 및 변 별타당도를 만족시킴을 알 수 있다.

\section{구조모형 분석}

먼저 어머니 놀이참여변인의 구조모형 분석을 실시한 결과는 다음과 같다. 구조모형의 적합도를 살펴본 결과 카이제곱 값 은 97.25로 나타났으며, CMIN/DF는 1.99, GFI는 .93, TLI는 $.97, \mathrm{CFI}$ 는 .98 , RMSEA 지수는 .07 로 수용 가능한 지수를 갖는 것으로 나타났다. 변인 간의 경로계수 및 통계적 유의성을 살 펴본 결과는 Table 2 와 같다. 어머니의 놀이참여수준은 어머니 의 민감하게 인지하기 놀이참여태도 $(\beta=.51, p<.001)$ 와 어머 니의 반응적이고 즐겁게 놀기 놀이참여태도 $(\beta=.38, p<.001)$

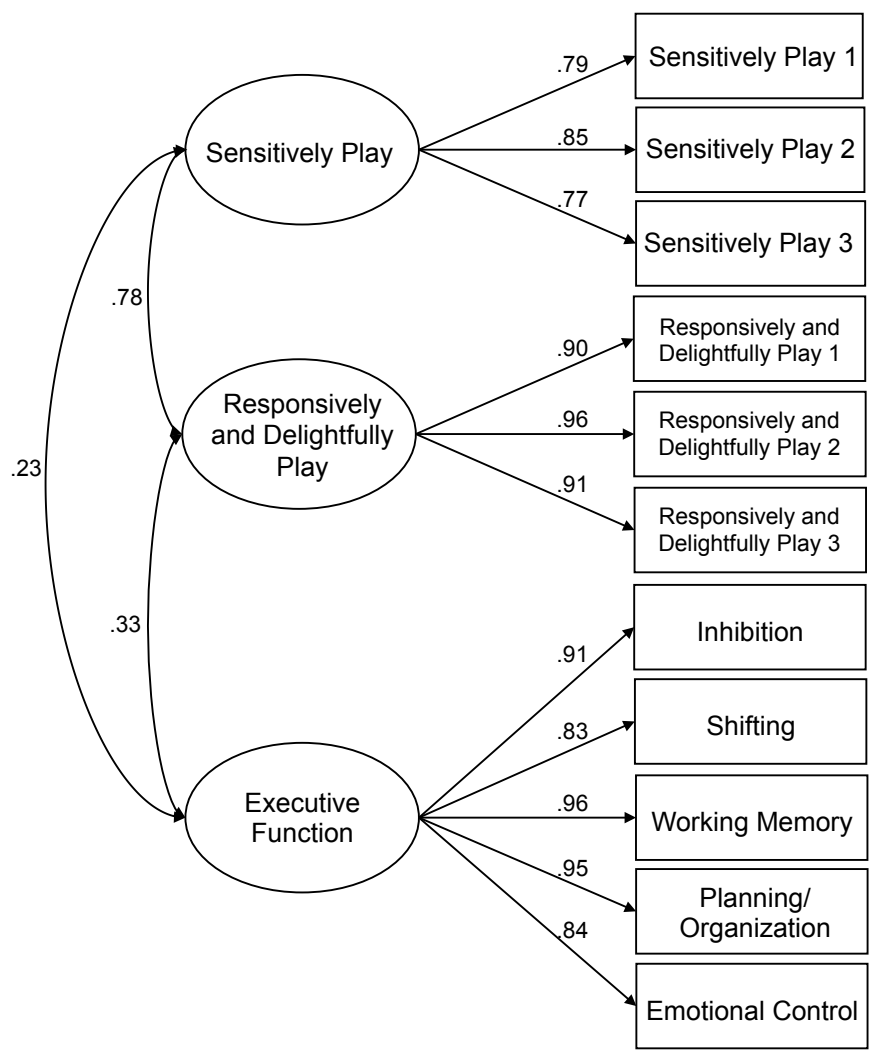

Figure 3. Confirmatory factor analysis of the measurement model of father's variables.

에 영향을 미치는 것으로 나타났다. 또한 어머니의 민감하게 인지하기 놀이참여태도는 어머니의 반응적이고 즐겁게 놀기 놀이참여태도에 영향을 미치는 것으로 나타났다 $(\beta=.55, p<$ .001). 어머니의 반응적이고 즐겁게 놀기 놀이참여태도는 유 아의 실행기능에 영향을 미치는 것으로 나타났다 $(\beta=.42, p<$ .01). 이를 토대로 한 구조모형은 Figure 4와 같다.

어머니의 놀이참여수준과 유아의 실행기능 간의 관계에서 어머니의 놀이참여태도를 매개로 한 직·간접효과를 살펴보 기 위해 부트스트래핑을 실시한 결과는 Table 3과 같다. 어머 니의 놀이참여수준이 어머니의 민감하게 인지하기 놀이참여 태도에 미치는 직접효과 $(\beta=.51, p<.001)$, 어머니의 반응적이 고 즐겁게 놀기 놀이참여태도에 미치는 직접효과 $(\beta=.38, p<$ $.001)$ 및 간접효과 $(\beta=.28, p<.001)$ 가 통계적으로 유의한 것 으로 나타났다. 또한 어머니의 민감하게 인지하기 놀이참여태 도가 어머니의 반응적이고 즐겁게 놀기 놀이참여태도에 미치 는 직접효과 $(\beta=.55, p<.001)$ 가 통계적으로 유의하였다. 어머 니의 놀이참여수준이 유아의 실행기능에 미치는 간접효과 $(\beta$ $=.33, p<.001)$, 어머니의 민감하게 인지하기 놀이참여태도가 유아의 실행기능에 미치는 간접효과 $(\beta=.23, p<.001)$ 가 통계 
Table 2

Path Estimates in the Structural Model of Mother's Variables

\begin{tabular}{|c|c|c|c|c|c|c|c|}
\hline \multicolumn{3}{|c|}{ Path of variables } & \multirow{2}{*}{$\begin{array}{r}B \\
.27\end{array}$} & \multirow{2}{*}{$\frac{\beta}{.51}$} & \multirow{2}{*}{$\begin{array}{c}S E \\
.04\end{array}$} & \multirow{2}{*}{$\frac{C R}{6.36}$} & \multirow{2}{*}{$\frac{p}{* * *}$} \\
\hline Play participation level & $\rightarrow$ & Sensitively play & & & & & \\
\hline Play participation level & $\rightarrow$ & Responsively and delightfully play & .29 & .38 & .05 & 6.01 & $* * *$ \\
\hline Sensitively play & $\rightarrow$ & Responsively and delightfully play & .78 & .55 & .12 & 6.60 & $* * *$ \\
\hline Sensitively play & $\rightarrow$ & Executive function & .11 & .11 & .14 & .85 & .40 \\
\hline
\end{tabular}

${ }^{* *} p<.01 .{ }^{* * *} p<.001$.

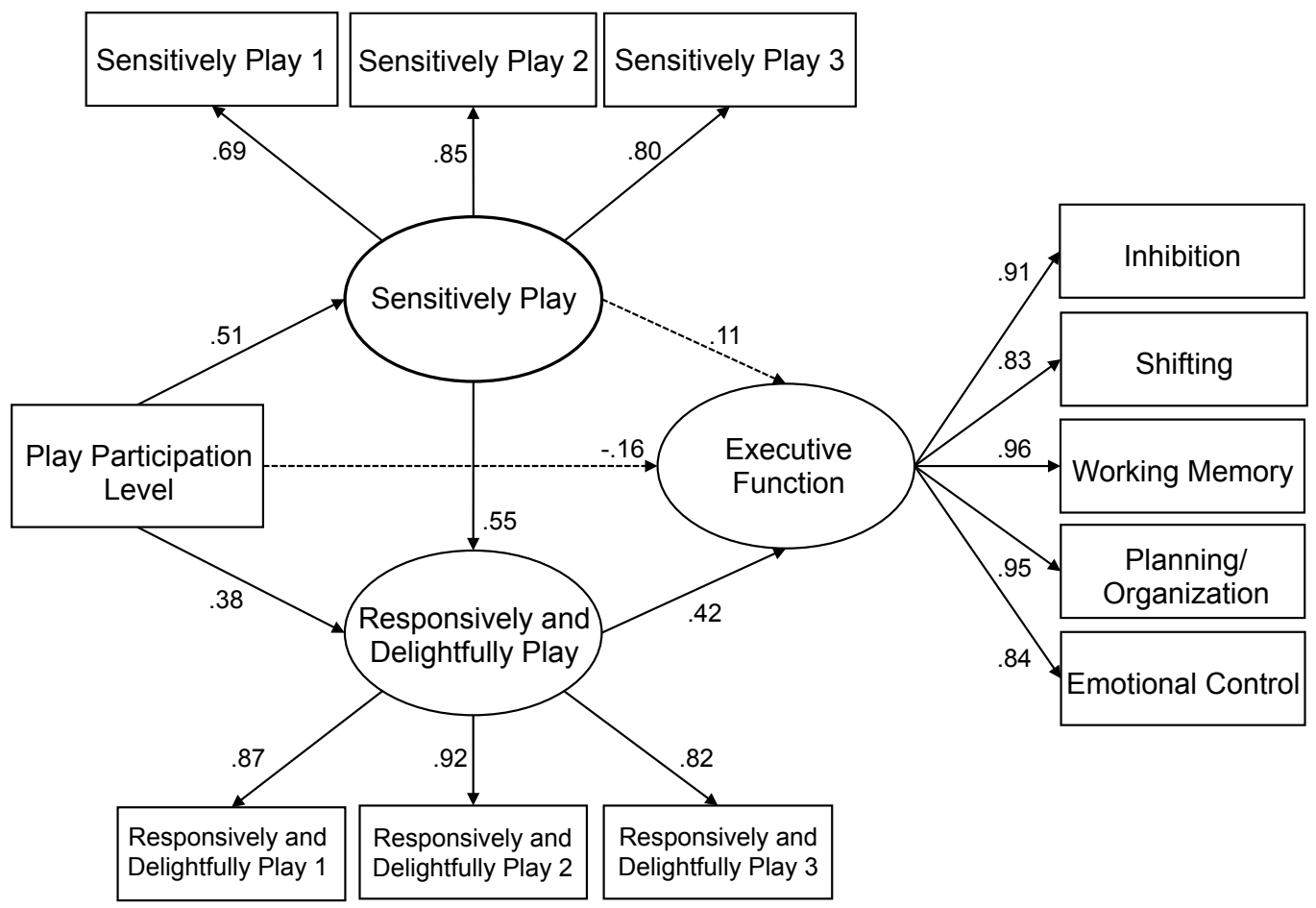

Figure 4. Standardized coefficients in the structural model of mother's variables.

적으로 유의하였다. 마지막으로, 어머니의 반응적이고 즐겁게 놀기 놀이참여태도가 유아의 실행기능에 미치는 직접효과 $(\beta$ $=.42, p<.001)$ 가 통계적으로 유의하였다. 종합해보면, 어머니 의 놀이참여수준은 어머니의 반응적이고 즐겁게 놀기 놀이참 여태도를 매개하여 유아의 실행기능에 영향을 미치는 경로가 유의한 것으로 나타났다. 또한 어머니의 놀이참여수준은 어머 니의 민감하게 인지하기와 반응적이고 즐겁게 놀기 태도를 이 중매개하여 유아의 실행기능에 간접적인 영향을 미치는 경로 가 유의한 것으로 나타났다.

어머니의 놀이참여수준과 유아의 실행기능 간의 관계에서 어머니의 놀이참여태도를 매개로 한 간접효과의 통계적 유의 성을 검증하기 위하여 부트스트래핑을 실시한 결과는 Table
4와 같다. 부트스트래핑을 실시할 때에는 반복추출 횟수를 5,000 번으로 하였고, $95 \%$ 기준으로 신뢰구간 값을 구하였다. 어머니의 놀이참여수준이 민감하게 인지하기와 반응적이고 즐겁게 놀기 놀이참여태도를 이중매개하여 실행기능에 영향 을 미치는 경로의 경우, 하한값과 상한값 사이의 구간에서 0 을 포함하지 않으므로 통계적으로 유의하였다. 마찬가지로, 어머 니의 놀이참여수준이 반응적이고 즐겁게 놀기 놀이참여태도 를 매개하여 실행기능에 영향을 미치는 경로의 경우, 하한값 과 상한값 사이의 구간에서 0 을 포함하지 않으므로 통계적으 로 유의하였다.

다음으로 아버지의 놀이참여변인 구조모형의 적합도를 살 펴본 결과 카이제곱 값은 104.18 로 나타났으며, $\mathrm{CMIN/DF}$ 는 
Table 3

Direct, Indirect, and Total Effects in the Structural Model of Mother's Variables

\begin{tabular}{|c|c|c|c|c|c|}
\hline \multicolumn{3}{|c|}{ Path of variables } & \multirow{2}{*}{$\frac{\text { Direct effect }}{.51^{* * *}}$} & \multirow{2}{*}{$\begin{array}{c}\text { Indirect effect } \\
-\end{array}$} & \multirow{2}{*}{$\begin{array}{c}\text { Total effect } \\
.51^{* * *}\end{array}$} \\
\hline Play participation level & $\rightarrow$ & Sensitively play & & & \\
\hline Play participation level & $\rightarrow$ & Responsively and delightfully play & $.38^{* * *}$ & $.28^{* * *}$ & $.66^{* * *}$ \\
\hline Sensitively play & $\rightarrow$ & Responsively and delightfully play & $.55^{* * *}$ & - & $.55^{* * *}$ \\
\hline Sensitively play & $\rightarrow$ & Executive function & .11 & $.23^{* * *}$ & $.34^{* *}$ \\
\hline
\end{tabular}
${ }^{*} p<.05 .{ }^{* *} p<.01 .{ }^{* * *} p<.001$.

Table 4

Bootstrapping Estimates and Confidence Intervals for Indirect Effects in the Structural Model of Mother's Variables

\begin{tabular}{lccc}
\hline \multicolumn{1}{c}{ Path of variables } & Effect & BootSE & BootLLCI \\
\hline $\begin{array}{l}\text { Play participation level } \rightarrow \text { Sensitively play } \rightarrow \\
\text { Responsively and delightfully play } \rightarrow \text { Exeutive function }\end{array}$ & .07 & .03 & .03 \\
$\begin{array}{l}\text { Play participation level } \rightarrow \text { Responsively and delightfully play } \rightarrow \\
\text { Executive function }\end{array}$ & .09 & .03 & .04 \\
\hline
\end{tabular}

Table 5

Path Estimates in the Structural Model of Father's Variables.

\begin{tabular}{|c|c|c|c|c|c|c|c|}
\hline \multicolumn{3}{|c|}{ Path of variables } & \multirow{2}{*}{$\begin{array}{l}B \\
.38\end{array}$} & \multirow{2}{*}{$\begin{array}{l}\beta \\
.64\end{array}$} & \multirow{2}{*}{$\begin{array}{l}S E \\
.04\end{array}$} & \multirow{2}{*}{$\frac{\mathrm{CR}}{8.86}$} & \multirow{2}{*}{$\frac{p}{* * *}$} \\
\hline Play participation level & $\rightarrow$ & Sensitively play & & & & & \\
\hline Play participation level & $\rightarrow$ & Responsively and delightfully play & .32 & .41 & .05 & 6.44 & $* * *$ \\
\hline Play participation level & $\rightarrow$ & Executive function & .00 & .00 & .05 & .04 & .97 \\
\hline Sensitively play & $\rightarrow$ & Responsively and delightfully play & .68 & .52 & .10 & 6.90 & $* * *$ \\
\hline Sensitively play & $\rightarrow$ & Executive function & -.06 & -.07 & .12 & -.52 & .60 \\
\hline Responsively and delightfully play & $\rightarrow$ & Executive function & .24 & .38 & .10 & 2.57 & * \\
\hline
\end{tabular}

${ }^{*} p<.05 .{ }^{* * *} p<.001$.

2.13, GFI는 .92, TLI는 .97, CFI는 .98, RMSEA 지수는 .08로 수 용 가능한 지수를 갖는 것으로 나타났다. 변인 간의 경로계수 및 통계적 유의성을 살펴본 결과는 Table 5 와 같다. 아버지의 놀이참여수준은 아버지의 민감하게 인지하기 놀이참여태도 $(\beta$ $=.64, p<.001)$ 와 아버지의 반응적이고 즐겁게 놀기 놀이참여 태도 $(\beta=.41, p<.001)$ 에 영향을 미치는 것으로 나타났다. 또한 아버지의 민감하게 인지하기 놀이참여태도는 아버지의 반응 적이고 즐겁게 놀기 놀이참여태도에 영향을 미치는 것으로 나 타났다 $(\beta=.52, p<.001)$. 아버지의 반응적이고 즐겁게 놀기 놀 이참여태도는 유아의 실행기능에 영향을 미치는 것으로 나타 났다 $(\beta=.38, p<.05)$. 이를 토대로 한 구조모형은 Figure 5 와 같 다.

아버지의 놀이참여수준과 유아의 실행기능 간의 관계에 서 아버지의 놀이참여태도를 매개로 한 직·간접효과를 살펴보
기 위해 부트스트래핑을 실시한 결과는 Table 6과 같다. 아버 지의 놀이참여수준이 아버지의 민감하게 인지하기 놀이참여 태도에 미치는 직접효과 $(\beta=.64, p<.001)$, 아버지의 반응적이 고 즐겁게 놀기 놀이참여태도에 미치는 직접효과 $(\beta=.41, p<$ $.001)$ 및 간접효과 $(\beta=.33, p<.001)$ 가 통계적으로 유의한 것으 로 나타났다. 또한 아버지의 민감하게 인지하기 놀이참여태도 가 아버지의 반응적이고 즐겁게 놀기 놀이참여태도에 미치는 직접효과 $(\beta=.52, p<.001)$ 가 통계적으로 유의하였다. 또한 아 버지의 놀이참여수준이 유아의 실행기능에 미치는 간접효과 $(\beta=.24, p<.01)$, 아버지의 민감하게 인지하기 놀이참여태도 가 유아의 실행기능에 미치는 간접효과 $(\beta=.20, p<.01)$ 가 통 계적으로 유의하였다. 마지막으로 아버지의 반응적이고 즐겁 게 놀기 놀이참여태도가 유아의 실행기능에 미치는 직접효과 $(\beta=.38, p<.05)$ 가 통계적으로 유의하였다. 종합해보면, 아버 


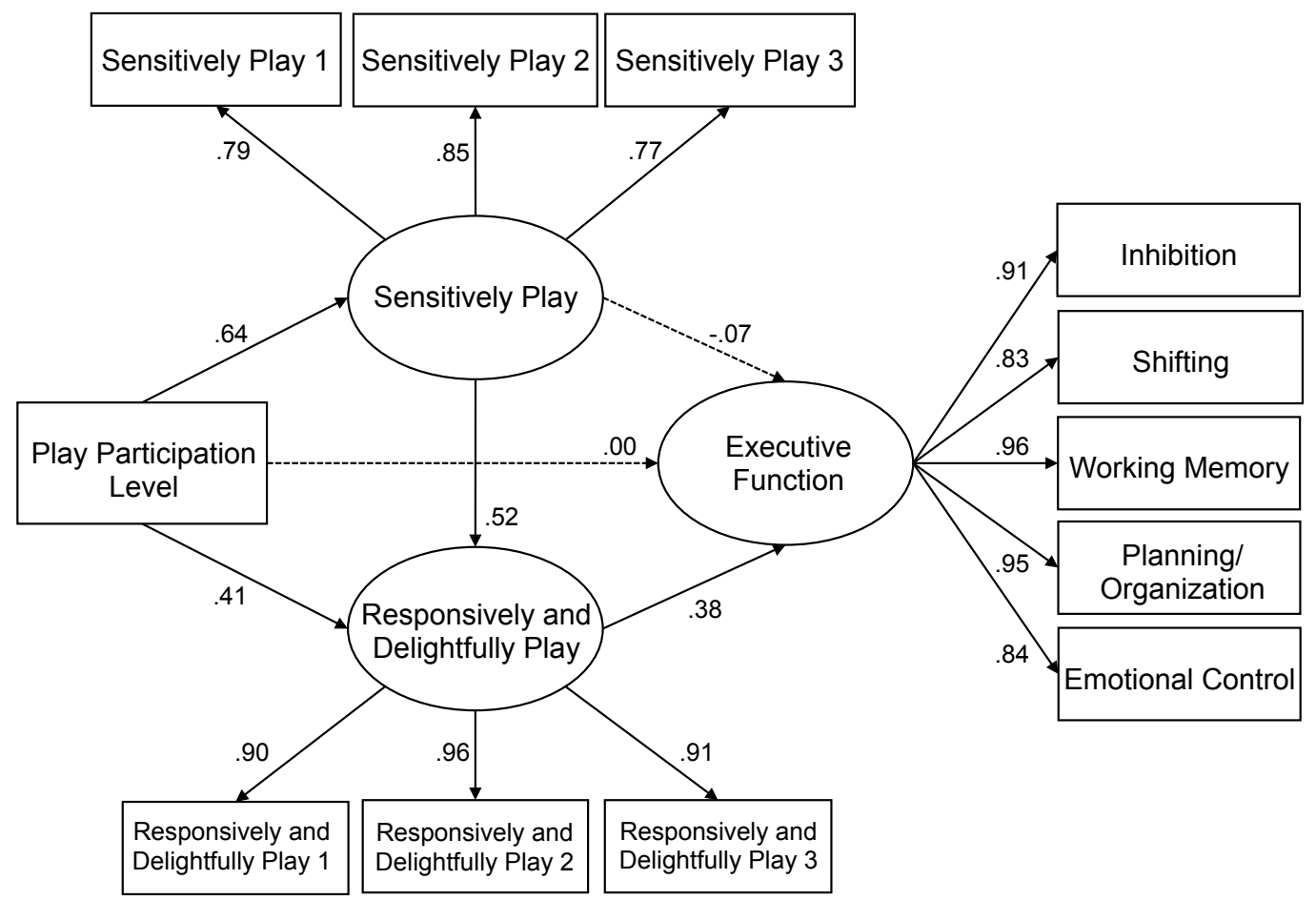

Figure 5. Standardized coefficients in the structural model of father's variables.

Table 6

Direct, Indirect, and Total Effects in the Structural Model of Father's Variables

\begin{tabular}{lcccc}
\hline & Path of variables & Direct effect & Indirect effect & Total effect \\
\hline Play participation level & $\rightarrow$ Sensitively play & $.64^{* * *}$ & - & $.64^{* * *}$ \\
Play participation level & $\rightarrow$ Responsively and delightfully play & $.41^{* * *}$ & $.33^{* * *}$ & $.74^{* * *}$ \\
Play participation level & $\rightarrow$ Executive function & .00 & $.24^{* *}$ & $.24^{* *}$ \\
Sensitively play & $\rightarrow$ Responsively and delightfully play & $.52^{* * *}$ & - & $.52^{* * *}$ \\
Sensitively play & $\rightarrow$ Executive function & -.07 & $.20^{* *}$ & .13 \\
Responsively and delightfully play & $\rightarrow$ Executive function & $.38^{*}$ & - & $.38^{*}$ \\
\hline
\end{tabular}

${ }^{*} p<.05 .{ }^{* *} p<.01 .{ }^{* * *} p<.001$.

Table7

Bootstrapping Estimates and Confidence Intervals for Indirect Effects in the Structural Model of Father's Variables

\begin{tabular}{lcccc}
\hline \multicolumn{1}{c}{ Path of variables } & Effect & BootSE & BootLLCI & BootULCI \\
\hline $\begin{array}{l}\text { Play participation level } \rightarrow \text { Sensitively play } \rightarrow \text { Responsively and delightfully play } \rightarrow \\
\text { Executive function }\end{array}$ & .06 & .03 & .02 & .14 \\
Play participation level $\rightarrow$ Responsively and delightfully play $\rightarrow$ Executive function & .08 & .03 & .02 & .16 \\
\hline
\end{tabular}

지의 놀이참여수준은 아버지의 반응적이고 즐겁게 놀기 놀이 참여태도를 매개하여 유아의 실행기능에 영향을 미치는 경로 가 유의한 것으로 나타났다. 또한 아버지의 놀이참여수준은 아버지의 민감하게 인지하기와 반응적이고 즐겁게 놀기 태도 를 이중매개하여 유아의 실행기능에 간접적인 영향을 미치는
경로가 유의한 것으로 나타났다.

아버지의 놀이참여수준과 유아의 실행기능 간의 관계에 서 아버지의 놀이참여태도를 매개로 한 간접효과의 통계적 유 의성을 검증하기 위하여 부트스트래핑을 실시한 결과는 Table 7 과 같다. 부트스트래핑을 실시할 때에는 반복추출 횟수를 
5,000 번으로 하였고, $95 \%$ 기준으로 신뢰구간 값을 구하였다. 아버지의 놀이참여수준이 민감하게 인지하기와 반응적이고 즐겁게 놀기 놀이참여태도를 이중매개하여 실행기능에 영향 을 미치는 경로의 경우, 하한값과 상한값 사이의 구간에서 0 을 포함하지 않으므로 통계적으로 유의하였다. 마찬가지로, 아버 지의 놀이참여수준이 반응적이고 즐겁게 놀기 놀이참여태도 를 매개하여 실행기능에 영향을 미치는 경로의 경우, 하한값 과 상한값 사이의 구간에서 0 을 포함하지 않으므로 통계적으 로 유의하였다.

\section{Discussion}

본 연구는 만 3, 4, 5세 유아의 어머니 및 아버지 193 쌍을 대상 으로 부모의 놀이참여수준과 유아의 실행기능 간의 관계에서 부모의 놀이참여태도의 매개효과를 확인함으로써 유아의 실 행기능 발달에 있어 부모와의 놀이의 중요성을 강조하고 부모 교육 프로그램 개발 및 부모상담에 도움이 될 수 있는 기초자 료를 제공하고자 한다. 주요 연구결과를 요약하고 논의한 뒤 결론을 내리면 다음과 같다.

첫째, 어머니 및 아버지의 놀이참여수준은 유아의 실행기능 과 정적 상관이 있었다. 이는 어머니 및 아버지가 놀이에 자주 참여할수록 유아의 실행기능 발달이 촉진됨을 의미한다. 이러 한 결과는 어머니가 유아와 놀이 활동이나 집안일을 하면서 함 께 시간을 자주 보낼수록 유아의 실행기능이 높았다는 연구결 과(Cha \& Kim, 2018) 및 아버지가 유아와 놀이하는 시간이 많 을수록 유아의 자기조절이나 과제수행행동과 같은 학습관련 기술에 긍정적인 영향을 미쳤던 연구결과(S. Y. Choi, 2017)와 부 분적으로 유사하다. 즉, 어머니 혹은 아버지와의 놀이경험 속에 서 유아는 주의집중 능력, 작업기억, 억제 능력 등과 같은 기술 들을 사용하고 조절해봄으로써 실행기능 발달을 촉진시킬 수 있다. 따라서 유아의 실행기능 발달을 도와주기 위해서는 어머 니 및 아버지가 유아와 자주 놀아주는 것이 필요하다.

둘째, 어머니 및 아버지의 민감하게 인지하기 놀이참여태도 와 반응적이고 즐겁게 놀기 놀이참여태도는 유아의 실행기능과 정적 상관이 있었다. 즉, 어머니 및 아버지가 민감하게 인지하는 놀이참여태도를 보일수록, 반응적이고 즐거운 놀이참여태도를 보일수록 유아의 실행기능이 높았다. 먼저 어머니 및 아버지의 민감하게 인지하기 놀이참여태도가 유아의 실행기능과 관련이 있었던 본 연구결과는 부모가 놀이상황에서 유아의 욕구를 민 감하게 인지하는 태도를 보일수록 유아의 자기조절능력이 높았
다는 연구결과(S. Lee et al., 2018)및 부모가 놀이상황에서 유아 의 신호를 민감하게 인지할수록 유아의 기억력, 문제해결력이 발달하였다는 연구결과(Tamis-LeMonda et al., 2004)와 유사하 다. 부모가 놀이를 하면서 유아가 어떤 놀이에 관심이 있는지 알 거나, 놀이하면서 느끼는 감정을 인지하거나, 유아가 하는 말이 나 행동의 의미를 민감하게 알아차릴수록 부모와 유아는 놀이 에 더욱 몰입할 수 있게 됨으로써 유아의 실행기능에도 긍정적 인 영향을 준 것으로 보인다.

다음으로, 어머니 및 아버지의 반응적이고 즐겁게 놀기 놀 이참여태도가 유아의 실행기능과 관련이 있었던 연구결과 는 부모가 놀이상황에서 유아를 격려하고 칭찬하거나 유아가 필요한 적절한 도움을 제공하고 반응적인 태도를 보일 때 유 아의 실행기능이 발달한다는 연구결과(Distefano et al., 2018; Merz et al., 2017)와 맥락을 같이 한다. 이러한 결과를 통해 어 머니 및 아버지가 놀이상황에서 유아가 흥미로워하는 놀이에 함께 관심을 기울이고 반응해주거나, 도움이 필요한 상황에 서 적절한 도움을 주거나, 유아의 눈높이에 맞춰 즐겁게 놀아 주는 등의 행동을 통해 놀이의 질이 높아짐으로써 유아의 실 행기능 발달을 촉진시킴을 알 수 있다. 결과적으로 유아의 실 행기능 발달을 촉진시키기 위해서는 부모가 놀이에 참여할 때 놀이상황에서 유아에 대해 민감하게 인지하고, 반응적이며 즐 겁게 놀아주는 태도를 보여주는 것이 필요하다고 할 수 있다.

셋째, 구조모형 분석 결과 어머니 및 아버지의 놀이참여수 준이 유아의 실행기능에 영향을 미치는 직접적인 경로는 유 의하지 않았으며, 어머니 및 아버지의 놀이참여수준이 어머 니 및 아버지의 반응적이고 즐겁게 놀기 놀이참여태도를 매개 로 유아의 실행기능에 영향을 미치는 간접적인 경로가 유의하 였다. 즉, 어머니 및 아버지가 유아와 자주 놀아줄수록 놀이에 더욱 반응적이고 즐겁게 참여하게 되어 유아의 실행기능 발달 을 촉진시킬 수 있었다. 이는 단순히 부모의 높은 놀이참여수 준만으로 유아의 실행기능이 발달된다기보다는 높은 놀이참 여수준을 통해 부모가 유아에 대해 반응적이고 즐거운 태도를 보임으로써 유아의 실행기능 발달에 촉진적인 역할을 한다는 사실을 제시해준다. 이러한 결과는 아버지가 주중에 유아와의 놀이 활동에 자주 참여할수록 유아에게 더욱 온정적이고 격 려하는 양육행동을 보이며(G. Y. Kim \& Shin, 2013) 유아와 아 버지의 친밀감이 높았다는 연구결과(J. Choi, 2004)와 유사한 맥락이다. 즉, 부모가 놀이에 자주 참여하게 되면 부모와 유아 는 긍정적인 상호작용을 자주 주고받으면서 관계가 친밀해지 기 때문에 부모가 유아에 대해 더욱 반응적이고 격려하는 태 도를 보이기 쉬움을 알 수 있다. 또한 부모의 이러한 태도는 유 
아로 하여금 자유롭게 환경을 탐색하게 하며 자발적이고 주도 적으로 놀이를 이끌어나가게 하여(Bernier, Carlson, Deschênes, \& Matte-Gagné, 2012; J. J. Kim \& Park, 2017) 유아의 실행기능 발달을 촉진시킬 수 있다. 유아의 실행기능 발달은 부모의 놀이 참여가 놀이상황에서 부모가 어떠한 태도를 촉진시킴으로써 유아의 실행기능 발달에 긍정적인 역할을 하는지 밝힌 의미 있 는 결과이다. 따라서 유아의 실행기능 발달을 도모하기 위해서 는 부모가 놀이에 자주 참여하고 유아의 신호에 적극적으로 반 응하고 즐겁게 놀아주는 태도를 보여주는 것이 필요하다.

넷째, 어머니 및 아버지의 놀이참여수준이 어머니의 민감 하게 인지하기 놀이참여태도와 반응적이고 즐겁게 놀기 놀이 참여태도를 이중 매개하여 유아의 실행기능에 영향을 미치는 간접적인 경로도 유의한 것으로 나타났다. 이는 인지적 태도 가 행동적 태도에 영향을 미친다고 밝힌 연구(S.-J. Kim et al., 2002; K. H. Park \& Yoo, 2012)에 의해 지지될 수 있다. 즉, 어머 니 및 아버지가 유아와의 놀이에 자주 참여할수록 유아에 대 해 민감하게 인지할 수 있게 되고, 놀이에서 적절한 반응을 하 거나 즐겁게 참여할 수 있게 되어 유아의 실행기능 발달을 촉 진시킬 수 있다. 이는 부모가 높은 수준의 놀이참여를 통해 유 아의 기분이나 상태 및 눈높이를 잘 이해할 수 있게 되면 유아 에게 칭찬 및 공감과 같은 즉각적인 반응을 보이거나 즐겁게 놀아줄 가능성이 높아지며, 이러한 과정은 유아의 실행기능에 긍정적인 영향을 미침을 보여준다. 부모의 잦은 놀이참여를 통해 축적된 유아에 대한 부모의 인지적 이해가 행동적 반응 에 영향을 미친다고 밝히고 있는 선행연구는 없으나 본 연구 에서 추론을 통해 검증함으로써 이와 같은 인과과정을 통해서 도 유아의 실행기능 발달에 도움을 줌을 알 수 있었다.

한편, 어머니 및 아버지의 놀이참여수준이 어머니 및 아버 지의 민감하게 인지하기 놀이참여태도를 매개로 유아의 실행 기능에 영향을 미치는 간접적인 경로는 유의하지 않았다. 다 시 말해, 어머니 및 아버지가 놀이에 자주 참여한다 하여도 유 아를 민감하게 인지하는 태도가 높아진 것만으로는 유아의 실 행기능 발달에 영향을 미치지 못했다. 어머니 및 아버지가 유 아를 민감하게 인지하는 놀이참여태도는 부모의 내적 인지과 정으로, 이러한 과정은 외적으로 표현되지 않기 때문에 유아 에게는 직접적으로 영향을 미치지 않은 것으로 보인다. 본 결 과는 부모의 인지과정이 반응적이고 즐겁게 노는 행동을 통해 외부적으로 표현됐을 때 유아의 실행기능에 긍정적인 역할을 할 수 있음을 보여준다.

또한 본 연구에서 어머니와 아버지의 놀이참여변인이 동 일한 과정을 통해 유아의 실행기능 발달에 영향을 미치는 것
이 확인되었다. 부모의 양육변인과 관련된 대부분의 연구에서 는 어머니와 아버지의 양육변인이 유아의 발달에 영향을 미 치는 과정에 있어 차이성을 보고하고 있으나(Baek, 2019; Son $\&$ Lee, 2008) 본 연구결과와 같이 부모의 놀이변인에 있어서 는 유아발달에 동일한 과정을 통해 영향을 미쳤던 연구 또한 살펴볼 수 있다(H. Lee \& Chung, 2016). 여전히 양육에 있어서 는 아버지보다 어머니가 훨씬 더 많은 시간 참여하는 경향이 있기 때문에(Ministry of Health and Welfare, 2018) 부모의 양육 변인과 유아의 발달에 관련된 연구에서 어머니와 아버지의 영 향력에서 차이가 나타나는 경우가 많다. 그러나 아버지의 주 된 양육참여 방법은 놀이로, 어머니와 아버지의 주말놀이참여 시간에서 큰 차이가 없다는 연구결과를 고려해볼 때(H. Lee \& Chung, 2016) 본 연구에서 어머니와 아버지의 동일한 경로가 나타난 이유는 놀이상황에 초점을 맞추었기 때문으로 생각해 볼 수 있다. 유아의 실행기능에 관한 선행연구는 어머니 변인 위주로 진행되어 옴에 따라 상대적으로 아버지 변인과 관련 된 연구가 제한적이었으나 본 연구결과를 통해 어머니와 아버 지의 놀이변인이 동일한 과정을 통해 유아의 실행기능 발달에 도움을 줄 수 있음을 알 수 있었다. 반면, 어머니의 놀이참여도 가 높을수록 유아의 사회적 유능성에 긍정적인 영향을 미치나 아버지의 놀이참여도는 유아의 사회적 유능성에 영향을 미치 지 않았던 연구(Shin, 2019) 및 어머니의 놀이참여수준이 높을 수록 유아의 자기조절능력이 높았으나 아버지의 놀이참여 수 준은 유아의 자기조절능력과 관련이 없었던 연구(H.-S. Choi $\& \mathrm{Kim}, 2011)$ 와 같이 상반된 결과도 보고되고 있다. 따라서 본 연구결과를 모든 부모와 유아를 대상으로 적용할 때에는 주의 할 필요가 있다. 본 연구는 어머니 및 아버지의 놀이변인과 유 아의 실행기능 간의 관계에 대한 초기 연구로, 추후 연구를 통 해 이들 간의 관계에 대한 연구가 활발히 이루어진다면 보다 명확한 정보를 제공할 수 있을 것으로 보인다.

본 연구의 의의는 다음과 같다. 첫째, 유아의 실행기능 발달 에 있어 부모역할의 중요성을 밝히는 연구가 활발히 진행되고 있으나 부모의 놀이참여에 관한 연구는 제한적이었다. 본 연 구를 통해 어머니 및 아버지의 놀이참여수준과 놀이참여태도 와 유아의 실행기능 간의 관련성을 확인함으로써 유아의 실행 기능에 대한 부모역할에 관한 연구를 확장시킬 수 있었다. 둘 째, 어머니 및 아버지가 단순히 놀이에 자주 참여하는 것 자체 보다는 이를 통해 반응적인 놀이참여태도를 보이거나, 유아에 대해 민감하게 인지함으로써 반응적인 태도를 보이는 것이 유 아의 실행기능 발달에 도움을 줄 수 있음을 확인하였다. 이를 통해 유아의 실행기능 증진을 위해서는 가정에서 부모가 유아 
와 자주 놀아주면서 어떤 생각과 행동에 초점을 맞추어야 하 는지에 대한 방향성을 제시하였다는데 의의가 있다. 마지막 으로, 유아의 실행기능 발달에 있어 상대적으로 아버지 역할 에 대한 정보가 제한적이었다. 그러나 본 연구에서 유아의 실 행기능 발달을 촉진시키기 위해서는 어머니 뿐 아니라 아버지 의 놀이변인 또한 중요함을 밝혔다. 본 연구를 통해 유아의 실 행기능 발달에 있어 부모의 놀이참여에 대한 중요성을 강조하 고, 부모가 놀이에 자주 참여하면서 유아를 민감하게 인지할 수 있는 부모의 인지적 놀이참여태도 및 반응적이고 즐겁게 놀아주는 부모의 행동적 놀이참여태도를 이끌어내는 데 초점 을 맞춘 부모교육 프로그램 개발 및 부모상담에 도움이 될 수 있는 기초 자료를 제공할 수 있을 것으로 생각된다.

추후 연구를 위하여 제언을 하면 다음과 같다. 첫째, 본 연 구의 연구대상자는 일부 지역에 한정되어 있기 때문에 연구결 과의 일반화에 무리가 있으므로 추후 연구에서는 다양한 지역 에 거주하는 유아와 부모를 대상으로 진행할 필요가 있다.

둘째, 본 연구에서는 어머니와 아버지가 모두 참여하여야 하는 연구방법의 특성상 설문지의 회수율이 낮았다는 제한점 이 있다. 이는 유아에 대해 소극적 관심을 보이는 부모보다는 적극적 관심을 보이는 부모가 다수 연구에 참여함으로써 연구 결과에 영향을 주었음을 의미할 수 있다. 또한 본 연구의 대상 은 만 $3,4,5$ 세이나 낮은 자료 회수율로 인해 실제 연구에 참 여한 유아의 연령이 만 5세에 편중되어 있다는 한계가 있다. 추후 연구에서는 회수율을 높일 수 있는 방법적 보완을 통해 연구를 진행한다면 더욱 객관적인 정보를 제공하여 연구의 결 과를 일반화하는데 도움이 될 것으로 생각된다.

셋째, 유아의 실행기능은 어머니와 아버지 보고식으로 측 정되었기 때문에 제 3 자가 보는 입장과 다소 차이가 있을 수 있다. 추후 연구에서는 유아교육기관의 선생님 보고식 측정 이 함께 이루어진다면 객관성 확보가 보다 가능할 것으로 보 인다. 또한 부모의 놀이참여수준과 놀이참여태도는 자기보고 식으로 측정되어 객관적인 측정이 어려웠을 수 있다. 따라서 추후에는 더 객관적인 측면에서 부모의 놀이변인을 측정할 수 있는 방법이 논의되어야 할 것이다.

\section{Acknowledgements}

This article is a part of the first author's Master's thesis submitted in 2020 .

\section{Notes}

This article was presented as a poster at the 2020 Annual Spring Conference of the Korean Association of Child Studies.

\section{Conflict of Interest}

No potential conflict of interest relevant to this article was reported.

\section{References}

\section{In English}

Blair, C., \& Razza, R. P. (2007). Relating effortful control, executive function, and false belief understanding to emerging math and literacy ability in kindergarten. Child Development, 78(2), 647-663. doi:10.1111/j.1467-8624.2007.01019.x

Bernier, A., Carlson, S. M., Deschênes, M., \& Matte-Gagné, C. (2012). Social factors in the development of early executive functioning: A closer look at the caregiving environment. Developmental Science, 15(1), 12-24. doi:10.1111/j.1467-7687.2011.01093.x

Bronstein, P., \& Cowan, C. P. E. (1988). Fatherhood today: Men's changing role in the family. Hoboken, NJ: John Wiley \& Sons.

Cemore, J. J., \& Herwig, J. E. (2005). Delay of gratification and makebelieve play of preschoolers. Journal of Research in Childhood Education, 19(3), 251-266. doi:10.1080/02568540509595069

Distefano, R., Galinsky, E., McClelland, M. M., Zelazo, P. D., \& Carlson, S. M. (2018). Autonomy-supportive parenting and associations with child and parent executive function. Journal of Applied Developmental Psychology, 58(2018), 77 85. doi:10.1016/j.appdev.2018.04.007

Ishii-Kuntz, M. (1994). Paternal involvement and perception toward fathers' roles: A comparison between Japan and the United States. Journal of Family Issues, 15(1), 30-48. doi:10.1177/019251394015001002

Isquith, P. K., Gioia, G. A., \& Espy, K. A. (2004). Executive function in preschool children: Examination through everyday behavior. Developmental Neuropsychology, 26(1), 403-422. doi:10.1207/s15326942dn2601_3

Kelly, R., Dissanayake, C., Ihsen, E., \& Hammond, S. (2011). The relationship between symbolic play and executive function in young children. Australasian Journal of Early Childhood, 36(2), 21-27. doi:10.1177/183693911103600204

Merz, E. C., Landry, S. H., Montroy, J. J., \& Williams, J. M. (2017). Bidirectional associations between parental responsiveness and 
executive function during early childhood. Social Development, 26(3), 591-609. doi:10.1111/sode.12204

Meuwissen, A. S., \& Carlson, S. M. (2015). Fathers matter: The role of father parenting in preschoolers' executive function development. Journal of Experimental Child Psychology, 140(2015), 1-15. doi:10.1016/j.jecp.2015.06.010

Moore, C., Barresi, J., \& Thompson, C. (1998). The cognitive basis of future-oriented prosocial behavior. Social Development, 7(2), 198-218. doi:10.1111/1467-9507.00062

NICHD Early Child Care Research Network. (2005). Predicting individual differences in attention, memory, and planning in first graders from experiences at home, child care, and school. Developmental psychology, 41(1), 99-114. doi:10.1037/0012-1649.41.1.99

Sokol, B., Muller, U., Carpendale, J.. Young, A., \& Iarocci, G. (2010). Self-and social-regulation: Social interaction and the development of social interaction, social understanding and executive functions. Cary, NC: Oxford University Press.

Tamis-LeMonda, C. S., Shannon, J. D., Cabrera, N. J., \& Lamb, M. E. (2004). Fathers and mothers at play with their 2and 3-year-olds: Contributions to language and cognitive development. Child development, 75(6), 1806-1820. doi:10.1111/j.1467-8624.2004.00818.x

Towe-Goodman, N. R., Willoughby, M., Blair, C., Gustafsson, H. C., Mills-Koonce, W. R., Cox, M. J., \& The Family Life Project Key Investigators. (2014). Fathers' sensitive parenting and the development of early executive functioning. Journal of Family Psychology, 28(6), 867-876. doi: $10.1037 / \mathrm{a} 0038128$

Ward, C. D. (1994). Adult intervention: Appropriate strategies for enriching the quality of children's play. Retrieved from ERIC database. (ED371844)

\section{In Korean}

Baek, H. J. (2019). A study of the factors affecting the frontal lobe function development of young children: Focusing on parenting behavior, parents-child communication, and interaction through reading books (Doctoral dissertation). Retrieved from http://www.riss.kr/link?id=T15366632

Cha, M. (2018). Relationships among preschoolers' executive function, preschool adjustment, school readiness, temperament, and maternal parenting (Doctoral dissertation). Retrieved from http://www.riss.kr/link?id=T14712237

Cha, M., \& Kim, K. (2018). The effects of temperament and maternal parenting on preschoolers' executive function. Journal of Parent Education, 10(1), 115-137.

Cho, I.-K., \& Kim, H.-J. (2005). The relationships between mothers' contingent shift behaviors and mothers' perceptions, parenting self-efficacy children's cognitive abilities, and mother-child mutual affect. Journal of early childhood education, 25(3), $5-30$.

Choi, H.-S., \& Kim, C.-S. (2011). The relationship between parents' participation in play and young children's selfregulation. The Journal of Korea Open Association for Early Childhood Education, 16(4), 117-133.

Choi, J. (2004). Father's play participation and child-father relationship, child's social competence (Master's thesis). Retrieved from http://www.riss.kr/link?id=T9842088

Choi, J. H. (2002). Relations among paternal involvement, parenting behaviors, and children's peer competence (Master's thesis). Retrieved from http://www.riss.kr/link?id=T8136038

Choi, S. Y. (2017). The influence of fathers' belief and participation in playing with children on children's learning related skill (Master's thesis). Retrieved from http://www.riss.kr/ link?id=T14567019

Hong, H. M. (2018). The mediation effect of executive function in the effects of mother's play participation on child's emotion regulation (Master's thesis). Retrieved from http://www.riss. $\mathrm{kr} /$ link?id=T15050137

Hong, Y. (2014). Exploration of instructional principles and developing instructional strategies for attitude formation and change (Doctoral dissertation). Retrieved from http://www. riss.kr/link?id=T13440428

Kim, B. Y. (2016). The effect of children's executive function, selfesteem and emotional intelligence on peer competence. Early Childhood Education \& Care, 11(3), 29-51. doi:10.16978/ ecec.2016.11.3.002

Kim, G. Y., \& Shin, H. Y. (2013). A study on variables related to paternal parenting behavior : Father involvement, parenting stress, and parenting self-efficacy. Journal of Korean Child Care and Education, 9(2), 191-213.

Kim, H. J. (1997). The variables related to father's child rearing practices and involvement behavior (Master's thesis). Retrieved from http://www.riss.kr/link?id=T937911

Kim, J. J., \& Park, H. S. (2017). The effects of father's play beliefs on play flow and peer play behavior of young children, with particular focus on the mediating effects of father's play participation. Korean Journal of Child Education and Care, 17(3), 29-48. doi:10.21213/kjcec.2017.17.3.29

Kim, L., \& Lee, S. (2018). A delphi study of item development of a play participation attitude scale for parents of preschoolers. Korean Journal of Play Therapy, 21(3), 379-397. doi:10.17641/KAPT.21.3.5

Kim, S.-J., Lee, K.-M., \& Lee, N.-M. (2002). The effects of behavior attitude on cognitive attitude on university students' dance sports. The Korean Journal of Physical Education, 41(3), 65-72.

Kim, Y.-M. (2018). The development of children's hot and cool executive function and relationship between language 
ability. Journal of Future Early Childhood Education, 25(3), 131-157. doi:10.22155/JFECE.25.3.131.157

Kong, Y. S. (2012). The effect of preschooler's temperament and maternal parenting attitude on preschooler's problem and prosocial behavior-Focusing on the mediating effect of executive function-(Doctoral dissertation). Retrieved from http:// www.riss.kr/link?id=T12699288

Kwon, J.-H. (2019). The relationship between mother's parenting anxiety, parenting behavior and preschool children's executive function: The moderating effect of mother's executive function (Master's thesis). Retrieved from http://www.riss.kr/ link?id=T15076967

Lee, H., \& Chung, H. (2016). The relationship among the parents' play beliefs, play participation and the child's happiness: Focused on the mediating effect of parents' play participation. Early Childhood Education and Care, 11(4), 77-95. doi:10.16978/ecec.2016.11.4.004

Lee, J.-E. (2013). The effects of mother's parenting efficacy and coaching competencies on child interaction (Master's thesis). Retrieved from http://www.riss.kr/link?id=T13275257

Lee, S., Wui, Y., Yoo, J., Chyung, Y., Lee, Y., \& Kim, L. (2018). The validation of the play participation attitude scale for parents of preschoolers. Korean Journal of Play Therapy, 21(4), 491-507. doi:10.17641/KAPT.21.4.4

Lee, Y.-J., Kong, Y.-S., \& Lim, J.-Y. (2014). The effects of parenting behaviors on preschoolers' executive function. Journal of Korean Home Management Association, 32(1), 1326. doi:10.7466/JKHMA.2014.32.1.13

Lim, J., \& Kim, S. (2020). The effects of mothers' coaching capability on creative personality and mother-child interaction in early childhood-Private education center co-parenting center's mothers-. The Journal of Education Research, 4(2), 25-49.

Ministry of Health and Welfare. (2018). 2018 junkookboyuksiltaejosagagujosa bogo-[2018년 전국보육실태조사 -가구조사 보고-] (Report No. 11-1352000-000961-12). Retrieved from MHW website: http://mohw.go.kr

Noh, Y.-M. (2006). Relationship between father's style of language control and play participation and the development of child's theory of mind (Master's thesis). Retrieved from http://www. riss.kr/link?id=T10669408

Park, E.-J. (2017). A study on influence of play style according to sex, age on infants executive function. Journal of the Korea Entertainment Industry Association, 11(1), 185-197. doi:10.21184/jkeia.2017.01.11.1.185
Park, K., \& Yoo, H. (2012). An analysis of the causal relationships between cognition, attitude, and behavior toward appearance management. Journal of the Korean Home Economics Association, 50(1), 51-63. doi:10.6115/khea.2012.50.1.051

Seo, J. (2011). The effects of executive function of children on emotional intelligence: A comparison between normal children and children with attention problems (Master's thesis). Retrieved from http://www.riss.kr/link?id=T12322340

Shin, I. N. (2019). Influence of parents' play involvement and playfulness on children's emotional intelligence and social competence (Master's thesis). Retrieved from http://www. riss.kr/link?id=T15015678

Son, N. S., \& Lee, S. H. (2008). Effects of the parenting attitude on children's social abilities from age 4 to age 6. Journal of Future Early Childhood Education, 15(2), 49-77.

Song, S.-Y. (2016). The effects of mothers' perceptions of types and causes of young children's challenging behaviors on their instructional methods for young children's challenging behaviors: Comparison between mothers with young children with disabilities and those with young children without disabilities (Master's thesis). Retrieved from http://www.riss. $\mathrm{kr} /$ link?id=T14180140

Won, H.-Y. (1998). A study on the relation between father's play participation level and child's social ability. Journal of Child Studies, 1998(2), 139-141.

Yoo, R. H., \& Kim, S. H. (2017). The relationship between mothers' affective parenting and preschoolers' peer competence: Mediating effects of preschoolers' executive function and emotion regulation. Korean J Child Stud, 38(2), 67-79. doi:10.5723/kjcs.2017.38.2.67

Yoo, Y. (2019). The effect of parental play involvement on 3-year-old children's peer relationship skills (Master's thesis). Retrieved from http://www.riss.kr/link?id=T15111608

\section{ORCID}

Sun Jung Baik https://orcid.org/0000-0001-9139-7581

Hee Hwa Kim https://orcid.org/0000-0003-0829-3226

Received August 30, 2020

Revision received October 23, 2020

Accepted November 10, 2020 